\title{
Kurumsal Yönetim, Kurumsal Sürdürülebilirlik ve Kurumsal İtibar Arasındaki İlişki: Borsa İstanbul
}

\author{
Mehmet TAŞKIRMAZ* Canan Gamze BAL**
}

$\ddot{O} Z$

Araştırmanın amacı kurumsal yönetim, kurumsal sürdürülebilirlik ve kurumsal itibar arasında bir ilişki olup olmadı̆̆ııı ve ĕger bir ilişki varsa nasıl bir ilişki olabileceğinin ortaya çıkarılmasıdır. Bu bağlamda kurumsal yönetim, kurumsal sürdürülebilirlik ve kurumsal itibar kavramları, bu çalışmanın konusunu oluşturmaktadır.

Serbest piyasa ve devlet; kurumsal yönetim, sürdürülebilirlik ve itibar konularına oldukça ilgi göstermektedir. Bu kurumlar/kuruluşlar kurumsal yönetim ve kurumsal sürdürülebilirlik uygulamalarıyla kendi kurumsal itibarlarını zenginleştirebilirler.

Araştırma kapsamındaki değişkenlerin analizi sonucunda kurumsal yönetim, kurumsal sürdürülebilirlik ve kurumsal itibar arasında güçlü bir pozitif ilişki bulunduğu açı̆̆a çıkarılmıştır. Buna ilaveten Johansen testine göre, kurumsal yönetim ve kurumsal sürdürülebilirliğin uzun dönemde birlikte hareket ettikleri ifade edilebilir. Ayrıca, araştırma kapsamındaki yüksek itibara sahip örneklem firmaların derin bir şekilde incelenmesi sonucunda kurumsal yönetim ve sürdürülebilirliğin, itibar ile pozitif ilişsi içerisinde bulunduğu belirtilebilir.

Sonuç olarak, kurumsal yönetim, kurumsal sürdürülebilirlik ve kurumsal itibar arasında pozitif güçlü bir ilişkinin olduğu ifade edilebilir.

Anahtar Kelimeler: Kurumsal Yönetim, Sürdürülebilirlik, İtibar

JEL Sinıflandırmast: G34, Q56, L14

\section{Relationship Between Corporate Governance, Corporate Sustainability and Corporate Reputation: A Sample of Borsa İstanbul}

\section{ABSTRACT}

This paper is aim to investigates that how relationship there is corporate governance, corporate sustainability and corporate reputation. In this context, corporate governance, corporate sustainability and corporate reputation concepts constitutes research issue of the paper.

Private and public corporations rather matters corporate governance, corporate sustainability and corporate reputation. Firms which have completed their institutionalizations is aware of the crucial importance of sustainability applications. These corporations can enhance their reputations with corporate governance principles and corporate sustainability applications.

As a result of analysis, there is a strong positive correlation between corporate governance and corporate sustainability. Further, according to Johansen test it is very likely that corporate governance and corporate sustainability could act together in the long term. Also, firms of sample that have high score in the rank of reputation implies that corporate governance and corporate sustainability could be positively associated with corporate reputation.

Consequently, there may be very likely a cohesion between corporate governance, corporate sustainability and corporate reputation.

Key Words: Corporate Governance, Sustainability, Reputation

JEL Classification: G34, Q56, L14

\footnotetext{
* Öğrenci, Kahramanmaraş Sütçü İmam Üniversitesi SBE İşletme Bölümü, mehmettaskirmaz@gmail.com

** Doç. Dr., Kahramanmaraş Sütçü İmam Üniversitesi İ̈BF İșletme Bölümü, canan_gamze@ @otmail.com
} 


\section{INTRODUCTION}

This paper is aimed to find out a solution to the problem that "Is there a relationship between corporate governance, corporate sustainability and corporate reputation?". In spite of the fact that there are lots of research to examine relationship between corporate governance and corporate social responsibility, however there have not been any study to determine the cohesion between corporate governance, sustainability and reputation yet. Thus research issue is determined as to find out whether there is a relationship between corporate governance, sustainability and reputation or not. If so, it would tried to explain strengths and directions of the relationships.

Although corporate governance had been more important with such as Enron, WorldCom, Arthur Anderson, AIG and Parmalat scandals in 2000s, it dates back into the earlier period of 1990s, is a system that firms is directed and controlled, guides into shareholders relationship of firms, contains all rules and applications written or not, includes business owners, members of the board of directors, employees, customers, suppliers, credit institutions (Solomon and Solomon, 1999; Paul and Reich, 1997; Özsoy, 2011; Colley, 2004; Hussainey and Al-Najjar, 2012; Walls et al., 2012). Globalization phenomenon provides functional integration of the nations by facilitating distributions of economic activities in international area, ensures the integration of national capital markets to global financial markets. Thus globalization phenomenon, is a concept that complex and beyond internationalization, has emerged as an important development all of interesting stakeholders (Dicken, 1992; Özsoy, 2011). Except globalization some causes such as institutionalization, moving beyond the family business, curbing conflicts of interest in management structure has affected corporate governance as well.

With regard to corporate governance first of all referral codes, management boards of companies listed on the stock exchange have to comply, had been created with the report prepared under the leadership Sir Adrian Cadbury in 1992. It had been provided an area to the other countries that could form codes and principles with Greenbury Report, Hampel Report, Turnbull Report, Myners Report and OECD principles following Cadbury Report as well (Cadbury Report, 1992; Greenbury Report, 1995; Hampel Report, 1998; Turnbull Report, 1999; Myners Report, 2001; OECD, 1999; OECD, 2004). Corporate governance, can be expressed as processes which control and take into account the organizations, has basic values such as transparency, fairness, accountability and responsibility and also sustains management standards that save shareholders' rights and enhance corporate governance by providing institutional independence (ANAO and DPMC, 2006; Kamal and Deegan, 2013; Grant and McGhee, 2014). These standards that forced to convert imperative principles for certain institutions and foundations by legalize with policy makers as Sarbanes-Oxley Act both varies according to the cultural, historical and political conditions of the countries and reflects the political, social and economic goals. (Sarbanes-Oxley Act, 2002; Pauly and Reich, 1997; Detomasi, 2006). 
Whereas sustainability concept have become popular with the published Brundtland Report titled "Our Common Future" in 1987, first form of the concept dates back into the earlier period of 1900s (Christofi et al., 2012). According to Brundtland Report, sustainability concept is defined as to ensure that it meets the needs of the present without compromising the ability of future generations to meet their own needs (Brundtland Report, 1987). Sustainability, which means not to reduce and protect natural wealth's too, have been the focus of attention by governments, business administrator, local communities, voluntary institutions, civil society institutions and the other interested people and is the subject of the development challenges exhibited worldwide (Zsolnai, 2002; Isaksson and Steimle, 2009). Brundtland Report that highlights worth of shareholder referred that sustainability includes corporate social responsibility and sustainable development concepts (Christofi et al., 2012).

In the context of sustainability comprehension, in order not to reduce ecological wealth it is required to make positive environmental effects of firms or neutralize these impacts at least (Hart, 1997). This sustainability horizon which all elements of society focus on have been internalized and have been seen as the fulcrum for operational activities. If it is focused the question that what exactly is business sustainability, many definitions can be encountered in the literature. For instance Høgevold and Svensson define business sustainability as to reduce or eliminate the effects on the earth ecosystem of business activities to include the supply and demand chain. Many contrasting views as sustainability does not bring increased costs on the contrary sustainability decreases the business costs, maintains business profitability and further strengthens the returns (Nidumolu et al., 2009; Høgevold and Svensson, 2012).

Nowadays modern business that aware of the situation and can be defined as smart firms, have converted sustainability into the organization's value by internalizing the sustainability inevitably. Within the framework Freeman's shareholder theory (Freeman, 1984) and Azapagic's system approach (Azapagic, 2003), corporate governance is defined as all elements in organization is cointegrated by being harmonized sustainability elements which are economic, social and environmental structures.

Reputation is a form of campaign that needed to combat for business survival to exist as long as. Reputation damages which may be more dangerous than financial crisis might causes deep crisis even for huge companies. Turkish Language Association (TDK) defines reputation concepts alone as prestige and the state of being reliable to pay debt (http://www.tdk.gov.tr Erişim Tarihi: 27.07.2017). Owing to the fact that corporate reputation is connected with corporate image and corporate identity, it must bring clarity to this concepts. In this context whereas corporate identity refers to beliefs of members of the organization about what the organization characters, corporate image is stated as specifics which people outside the organization (customers, creditors, suppliers etc.) have used to distinguish the organization from others and organization members beliefs (Dutton and Dukerich, 1991). 
Corporate reputation concepts which it is very closely related to corporate identity and corporate image concepts collectively impressions about the firm that member of the social group. In addition to this, corporate reputation is defined as intangible resources of the company by leading competitive advantage (De Castro et al, 2006; Pfarrer et al., 2010; Chun, 2005; Deephouse, 2000; Schnietz and Epstein, 2005). Whereas there are many descriptions to explain corporate reputation in the literature, these definitions varies rather because of the fact that there are ideas for reputation an image that it covers the other one (Gotsi and Wilson, 2001). Although there are also many theory to explain corporate reputation in the literature, some theories such as attribution theory, agenda setting theory, issue ownership theory, impression management theory and signal theory mainly is mentioned many papers (Heider, 1958; McCombs and Shaw, 1972; Petrocik, 1996; Goffman, 1959; Porter, 1980; Spence, 1973).

The aim of the study is to uncover whether there is a relationship between corporate governance, corporate sustainability and corporate reputation or not. In this frame, first of all the studies in the literature related to corporate governance, corporate sustainability and corporate reputation will be touched on and research variables (corporate governance, corporate sustainability and corporate reputation) will be tried to explain. Secondly sample and methodology will be specified. Thirdly research results will be written down. Finally according to research findings a general assessment will be made.

\section{LITERATURE REVIEW}

Corporate governance, corporate sustainability and corporate reputation have not yet debated together, however there are many papers in the literature related to corporate governance and corporate social responsibility, corporate governance and corporate reputation, corporate social responsibility and corporate reputation or corporate governance and corporate sustainability.

In the context of corporate governance and corporate sustainability Janggu et al., approached the issue that is good corporate governance leads better sustainability reporting. In the frame of agency theory according to analyses that to examine the effects of good corporate governance on 100 public companies' sustainability disclosures and according to research analysis being used Structural Equation Modeling (SEM) it was explored that board size, board appointment and professionalism significantly affects sustainability disclosure (Janggu et al., 2014). Jo and Harjoto discussed corporate governance and corporate social responsibility together. According to Jo and Harjoto, corporate social responsibility is positively associated with internal/external corporate governance and monitoring mechanisms. Further, corporate social responsibility positively affects the firm's value as well (Jo and Harjoto, 2011).

In the frame of research scope another study was being examined is paper of Krechovská and Procházková. They indicates that entrepreneurs are aware of importance of sustainability to develop corporate performance in the long term (Krechovská and Procházková, 2014). These arguments supported by Krüger's opinions about that corporate social responsibility news which have strong legal 
and economic information contents provides quite stronger investor reaction (Krüger, 2014). According to Cong and Freedman's arguments which support the theory of legalization, not including exceptions environmental disclosure that a part of sustainability positively associated with good corporate governance (Cong and Freedman, 2011).

The other literature researcher Lewis had tried to explain how corporate social responsibility assessed by shareholder. Lewis emphasize that corporate social responsibility is a potential base to reassure between organization and shareholder (Lewis, 2003). According to Sharma and Khanna's paper related to corporate governance and corporate sustainability, there is a poor positive relation between corporate governance and corporate sustainability (Sharma and Khanna, 2014). Michelon and Parbonetti highlight that good corporate governance and sustainability disclosure is a complementary mechanism for organization and stakeholder dialogue (Michelon and Parbonetti, 2012). At the same frame Filatotchev and Nakajima' statements about that a kind of dialogue is formed with quality standards and sustainability supports sights of Michelon and Parbonetti (Filatotchev and Nakajima, 2014).

Jizi et al., stressed the relationship between elements of corporate governance and corporate social responsibility. According to research results of Jizi et al., board independence and size is positively associated with corporate social responsibility. Also Chief Executive Officer (CEO) duality positively affects corporate social responsibility disclosure (Jizi et al., 2014). Beside paper of Chan et al. is consistent with legalization and shareholder theory, Chan et al. point out companies providing more information on corporate social responsibility have better corporate governance degree, higher industry profile, higher leverage and greater structure (Chan et al., 2014). The other literature researcher is Stuebs and Sun's study. Their study based on shareholder theory explains that good corporate governance leads good corporate social responsibility performance (Stuebs and Sun, 2015).

It is generally explained existence of positive relationship between corporate governance and corporate sustainability/corporate social responsibility in the literature (Jo and Harjoto, 2011; Cong and Freedman, 2011; Janggu et al., 2014; Sharma and Khanna, 2014; Jizi et al., 2014; Chan et al., 2014; Stuebs and Sun, 2015). In this regard, it is expected that there may be positive correlation between corporate governance and corporate sustainability consistent with legalization and shareholder theory by having been had the same opinion. Also to being strong corporate governance contains transparency, fairness, accountability and responsibility elements, corporate social responsibility includes economic, environmental and social performance might positively affect corporate reputation. It is generally explained existence of positive relationship between corporate governance and corporate sustainability/corporate social responsibility in the literature (Jo and Harjoto, 2011; Cong and Freedman, 2011; Janggu et al., 2014; Sharma and Khanna, 2014; Jizi et al., 2014; Chan et al., 2014; Stuebs and Sun, 2015). 


\section{METHODOLOGY}

This paper is aim to investigates that how relationship there maybe corporate governance, corporate sustainability and corporate reputation. In this context, corporate governance, corporate sustainability and corporate reputation concepts constitutes research issue of the paper.

Borsa İstanbul Corporate Governance Index, Borsa İstanbul Corporate Sustainability Index and Brandfinance Turkey 100 was employed in this paper in order to explore the correlation between corporate governance, corporate sustainability and corporate reputation. In the research process it has been identified that there are 47 firms in Borsa İstanbul Corporate Governance Index (BIST XKURY), 15 firms in Borsa İstanbul Sustainability Index (BIST XUSRD) and 100 firms in Brandfinance Turkey 100. However both in BIST XKURY, BIST XUSRD and Brandfinance Turkey 100 rank is available common six firms. For this reason, it was examined common six firms in Brandfinance Turkey 100 rank in order to find out the effects of corporate governance and corporate sustainability on corporate reputation.

BIST XKURY, BIST XUSRD and Branfinance Turkey 100 was included in the analysis so as to explain the relationship between corporate governance, corporate sustainability and corporate reputation concepts. Firstly correlation analysis will be applied so as to determine direction and streghts of the relationship between corporate governance and corporate sustainability. Johansen system co-integration test (Johansen, 1991) was employed if BIST XKURY and BIST XURD indexes series act together in the long term or not. But to perform this test, Augmented Dickey Fuller (ADF) test (Dickey and Fuller, 1981) is needed to implement whether series of BIST XKURY and BIST XUSRD indexes stabilize in the time when taking first difference or not. Brandfinance Turkey 100 rank will be used to find out an answer to question that does corporate governance and corporate sustainability affect on corporate reputation. In this regard, ranks of common six firms will be interpreted in Brandfinance Turkey 100. By taking into accounts second session data in the time period between 04.11.2014-06.04.2015 dates for BIST XKURY and BIST XUSRD indexes. First of all, Pearson correlation coefficient (Pearson, 1895, 1900) will be used so as to measure direction and strengths of the relationship regardless to being dependent and independent variables. As Pearson correlation coefficient interpret BIST XKURY and BIST XUSRD scatterplot diagrams will be examined and it will be watched out whether outliers is available or not. Also sample size must not under thirty data (Sipahi et al., 2008). Hypothesis related to correlation analysis forms as below.

Hypothesis 1. There is a linear relationship between BIST XKURY Index and BIST XUSRD Index.

After correlation analysis, Johansen system co-integration test (Johansen, 1991) can be implemented. But it must be identify whether BIST XKURY and BIST XUSRD index series stabilize the same level or not. ADF test (Dickey and Fuller, 1979) is needed to being employed so as to determine BIST XKURY and 
BIST XUSRD index series' stability. Unlike DF test, autocorrelation problem is eliminated with ADF test which have the same process with DF. In addition to this, it is token logarithm of data of variables to stabilize average and variance of the BIST XKURY and BIST XUSRD index series (Y1ldirtan, 2011). In this case Hypotheses of ADF test is as below.

Hypothesis 2a. BIST XKURY Index; do not contains unit root, so it is stable. stable.

Hypothesis 2b. BIST XUSRD Index; do not contains unit root, so it is

Johansen system co-integration test was employed to explore whether the series act together in the long term or not. Vector Error Correction Model (VECM) is used with Johansen approach. Also, there are two specifics including short and long term (Johansen, 1991). Owing to the fact that it is available more than two variables in VECM, there can be multiple equilibrium relationship. However, (m-1) number of co-integration vector generally occurs for $(\mathrm{m})$ number of variables. According to VECM model if rank of $\Pi$ matrix $(r) \leq(m-1)$, there may be co-integration relationship between variables (Sevüktekin and Nargeleçekenler, 2010). Hypothesis related to co-integration is as below.

Hypothesis 3. There is at least one co-integration vector for BIST XKURY and BIST XUSRD Indexes.

Lastly, ranks of common six firms in BIST XKURY, BIST XUSRD and Brand finance Turkey 100 will be examined in order to explore that whether there is a relationship between corporate governance, corporate sustainability and corporate reputation. In this context, it will be observed that if total brand value of the group includes six common firms increase or not by year under investigation.

\section{RESEARCH FINDINGS}

Total 218 data for 109 days was analyzed in the time period between 04.11.2014-06.04.2015 dates for BIST XKURY Index and BIST XUSRD Index in research scope and there is any missing data. Firstly, Pearson correlation test was applied to determine relationship between said variables. As a result of correlation analysis, it was obtained positively strong correlation $(+0,965)$ between BIST XKURY Index and BIST XUSRD Index. As regard matrix scatterplot both BIST XKURY index and BIST XUSRD Index series do not scatter randomly, on the contrary both of them have a linear direction. In light of these data it was specified that correlation results of the series are significant substantially. Also, time and scatter plot graphic of BIST XKURY Index and BIST XUSRD Index series is shaped as below. 
Figure 1. Diagrams of BIST XKURY and BIST XUSRD Indexes

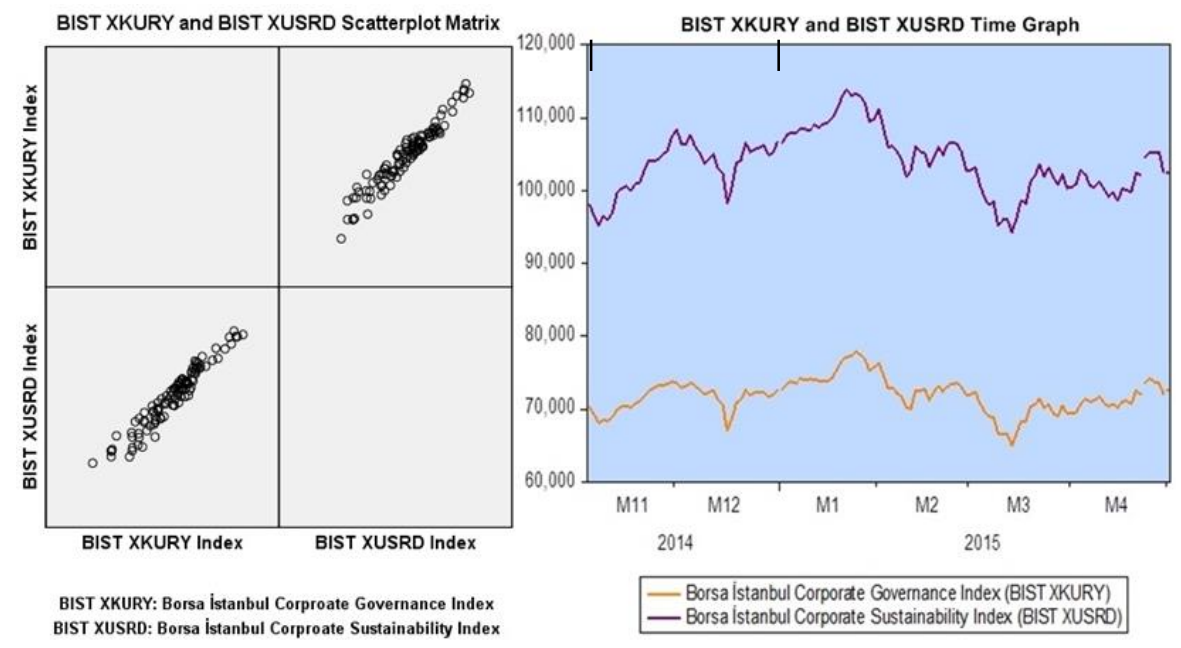

After examining correlation of the series, scatter plot diagram and time plot graphic, it was investigated if the series of BIST XKURY Index and BIST XUSRD Index act together in the long term or not. However ADF test (Dickey and Fuller, 1981) is employed to identify the issues if series of the indexes have unit root and stabilize at the same level or not before Johansen system cointegration analysis (Johansen, 1991). As a result of ADF test, whereas BIST XUSRD Index have 0,3084 critical value at the level, BIST XKURY Index have 0,2803 critical value at the level. Though, that's why both BIST XKURY Index and BIST XUSRD Index series significantly 0,0000 critical value when the series is applied with first difference, it is expressed that the series have not unit root, so both of them have stabilized. Because of this situation, Hypothesis $2 \mathrm{a}$ and Hypothesis $2 \mathrm{~b}$ are accepted. Johansen system co-integration analysis (Johansen, 1991) is employed to determine if BIST XKURY Index and BIST XUSRD Index series act or not together in the long term. VAR (3) model is appropriate for Johansen system co-integration analysis. As seen on Table 1, Trace Statistics and Max-Eigen Statistics values are statistically significance. For this reason, it may be said that the series of BIST XKURY Index and BIST XUSRD Index act together in the long term. Johansen system co-integration analysis results are showed on Table 1 and Table 2 as below.

Table 1. Trace Statistics of Johansen System Co-integration Analysis

\begin{tabular}{lllll}
\hline $\begin{array}{l}\text { Hypothesized } \\
\text { No. of CE(s) }\end{array}$ & Eigenvalue & $\begin{array}{l}\text { Trace } \\
\text { Statistics }\end{array}$ & $\begin{array}{l}\text { \%5 } \\
\text { Critical } \\
\text { Value }\end{array}$ & Probability \\
\hline $\mathrm{r}=0$ & 0.104619 & 18.94168 & 15.49471 & 0.0145 \\
$\mathrm{r} \leq 1$ & 0.069121 & 7.449105 & 3.841466 & 0.0063 \\
\hline
\end{tabular}


Table 2. Max-Eigen Statistics of Johansen System Co-integration Analysis

\begin{tabular}{lllll}
\hline $\begin{array}{l}\text { Hypothesized } \\
\text { No. of CE(s) }\end{array}$ & Eigenvalue & $\begin{array}{l}\text { Max-Eigen } \\
\text { Statistics }\end{array}$ & $\begin{array}{l}\text { \%5 } \\
\text { Critical } \\
\text { Value }\end{array}$ & Probability \\
\hline $\mathrm{r}=0$ & 0.104619 & 11.49257 & 14.26460 & 0.1312 \\
$\mathrm{r} \leq 1$ & 0.069121 & 7.449105 & 3.841466 & 0.0063 \\
\hline
\end{tabular}

As a result of Johansen system co-integration analysis, trace statistics value is larger than critical value. Also, because of the fact that max-eigen statistics value is higher level than critical value (7.449105>3.841466), there is one cointegration vector at least. According to these results, Hypothesis 3 is supported. In this case, it is accepted that BIST XKURY Index and BIST XUSRD Index act together in the long term. Positive relationship between BIST XKURY Index and BIST XUSRD Index is supported by literature too (Jo and Harjoto, 2011; Cong and Freedman, 2011; Janggu et al., 2014; Sharma and Khanna, 2014; Jizi et al., 2014; Chan et al.,2014; Stuebs and Sun, 2015).

Finally, common six firms take place in BIST XKURY Index, BIST XUSRD Index and Brandfinance Turkey 100 are examined to explore the effects of corporate governance and corporate sustainability on corporate reputation. Ranks of six common firms by year are shown below.

Table 3. Common Six Firms in Brandfinance Turkey 100

\begin{tabular}{|c|c|c|c|c|c|c|c|}
\hline $\begin{array}{c}2014 \\
\text { ran } \\
k\end{array}$ & $\begin{array}{c}201 \\
5 \\
\operatorname{ran} \\
\mathbf{k} \\
\end{array}$ & Brand & $\begin{array}{c}2014 \\
\text { Brand } \\
\text { Value } \\
\text { (Milion \$) }\end{array}$ & $\begin{array}{c}2015 \\
\text { Brand } \\
\text { Value } \\
\text { (Milion \$) }\end{array}$ & Change & $\begin{array}{c}2014 \\
\text { Brand } \\
\text { Degre } \\
\text { e }\end{array}$ & $\begin{array}{c}2015 \\
\text { Brand } \\
\text { Degre } \\
\text { e }\end{array}$ \\
\hline 1 & 2 & Türk Telekom & 2,000 & 2,475 & + & AAA- & $\mathrm{AA}+$ \\
\hline 5 & 6 & Arçelik & 1,616 & 1,845 & + & AA+ & AA \\
\hline 7 & 5 & Garanti & 1,364 & 1,953 & + & AAA- & $\mathrm{AA}+$ \\
\hline 10 & 8 & Yap1Kredi & 1,099 & 1,393 & + & $\mathrm{AA}+$ & AA \\
\hline 31 & 34 & TAV & 174 & 152 & - & A+ & $A+$ \\
\hline 38 & 47 & Aselsan & 134 & 112 & - & $\mathrm{AA}+$ & AA- \\
\hline
\end{tabular}

Data in the time period between 04.11.2014-06.04.2015 dates for BIST XKURY and BIST XUSRD indexes was separated to two groups and average scores of each groups was applied so as to demonstrate clearly the effects of corporate governance and corporate sustainability on corporate reputation. In this way, average data for BIST XKURY Index and BIST XUSRD Index was formed by belonging to 2014 and 2015 years. These data was indicated on Table 4 as below. 
Table 4. The Data of BIST XKURY, BIST XUSRD and Brandfinance Turkey 100

\begin{tabular}{cccc}
\hline & $\begin{array}{c}\text { BIST XKURY } \\
\text { Index } \\
\text { (Average) }\end{array}$ & $\begin{array}{c}\text { BIST XUSRD } \\
\text { Index } \\
\text { (Average) }\end{array}$ & $\begin{array}{c}\text { Common Six Firms Total Brand } \\
\text { Value } \\
\text { (Million \$) }\end{array}$ \\
\hline 2014 & 71487,07 & 103003,00 & 6387 \\
year & & 104750,28 & 7930 \\
2015 & 72153,30 & & \\
year & & & \\
\hline
\end{tabular}

As data on the Table 4 is examined, it was explored that BIST XKURY Index average, BIST XUSRD Index average and total brand value of six common firms have been increased. The papers which explain effects of corporate governance or corporate sustainability on corporate reputation is rather available in the literature (Fombrun and Shanley, 1990; Musteen et al., 2010; Brammer and Pavelin, 2006; Melo and Garrido-Morgado, 2012). When the research results are assessed, there is a positive relationship between corporate governance, corporate sustainability and corporate reputation.

\section{CONCLUSIONS}

This paper is aimed to find out a solution to the problem that "Maybe there is a relationship between corporate governance, corporate sustainability and corporate reputation?".

First of all, Pearson correlation test was applied to determine relationship between variables. As a result of correlation analysis, it was obtained positively strong correlation $(+0,965)$ between BIST XKURY Index and BIST XUSRD Index. According to Pearson correlation results $(+0,965)$, Hypothesis 1 is supported. As a result of ADF test, whereas BIST XUSRD Index have 0,3084 critical value at the level, BIST XKURY Index have 0,2803 critical value at the level. Though, that's why both BIST XKURY Index and BIST XUSRD Index series significantly 0,0000 critical value when the series is applied with first difference, it is expressed that the series have not unit root, so both of them have stabilized. Because of this situation, Hypothesis 2a and Hypothesis $2 \mathrm{~b}$ are accepted. Johansen system co-integration analysis (Johansen, 1991) is employed to identify if BIST XKURY Index and BIST XUSRD Index series act or not together in the long term. As a result of Johansen system co-integration analysis, trace statistics value is greater than critical value. Also, because of the fact that max-eigen statistics value is higher level than critical value (7.449105>3.841466), there is one co-integration vector at least. According to these results, Hypothesis 3 is supported. In this case, it is accepted that BIST XKURY Index and BIST XUSRD Index act together in the long term. Positive relationship between BIST XKURY Index and BIST XUSRD Index is supported by literature too (Jo and Harjoto, 2011; Cong and Freedman, 2011; Janggu et al., 2014; Sharma and Khanna, 2014; Jizi et al., 2014; Chan et al., 2014; Stuebs and Sun, 2015). Lastly, common six firms take place in BIST XKURY Index, BIST XUSRD Index and Brandfinance Turkey 100 are examined to explore the effects of corporate governance and corporate sustainability on corporate reputation. It was explored 
that BIST XKURY Index average, BIST XUSRD Index average and total brand value of six common firms have been increased. The papers which explain effects of corporate governance or corporate sustainability on corporate reputation is rather available in the literature (Fombrun and Shanley, 1990; Musteen et al., 2010; Brammer and Pavelin, 2006; Melo and Garrido-Morgado, 2012). When the research results are assessed, there is a positive relationship between corporate governance, corporate sustainability and corporate reputation.

Within the framework Freeman's shareholder theory (Freeman, 1984) and Azapagic's system approach (Azapagic, 2003), corporate governance is cointegrated by being harmonized sustainability elements which are economic, social and environmental structures. These two structures (governance and sustainability) in the organization will leads on enhanced corporate repautation. Finally the triple column which is essential for the organization will make organizations successful.

As regard financial, environmental and social, corporate governance and corporate sustainability is linked with. Also, these indicator for the organization indirectly affect on corporate reputation of the firm. Research results indicate that there is very likely positive relationship between corporate governance, corporate sustainability and corporate reputation. With regard to researcher in corporate governance, corporate sustainability and corporate reputation literature, depth researches that how the variables of corporate governance and corporate sustainability affect on corporate reputation may investigated.

\section{REFERENCES}

ANAO (Australian National Audit Office) \& DPMC (Department of the Prime Minister and Cabinet). (2006). Implementation Of Programme and Policy Initiatives, Making Implementation Matter Better Practice Guide. https://www.implementation.eu Erişim Tarihi: 27.07.2017.

Azapagic, A. (2003). Systems Approach to Corporate Sustainability. Institution of Chemical Engineers. 8, Part B. 303-316.

Brammer, S. J. \& Pavelin, S. (2006). Corporate Reputation and Social Performance: The Importance of Fit, Journal of Management Studies. 43(3). 435-455.

Brundtland Report. (1987). Our Common Future. http://www.un-documents.net Erişim Tarihi: 27.07.2017.

Cadbury Report, (1992). Report of the Committee on the Committee on the Financial Aspects of Corporate Governance. http://www.ecgi.org Erişim Tarihi: 27.07.2017.

Chan, M., Watson, J. \& Woodliff D. (2014). Corporate Governance Quality and CSR Disclosures. J Bus Ethics. 125. 59-73.

Christofi, A., Christofi, P. \& Sisaye, S. (2012). Corporate Sustainability: Historical Development and Reporting Practices. Management Research Review. 35(2). 157-172.

Chun R. (2005). Corporate Reputation: Meaning and Measurement. International Journal of Management Reviews. 7(2). 91-109.

Colley, J. L. (2004). What is Corporate Governance?. Ohio: McGraw-Hill Professional Publishing.

Cong, Y. \& Freedman, M. (2011). Corporate Governance and Environmental Performance and Disclosures. Advances in Accounting, Incorporating Advances in International Accounting. 27. 223-232.

De Castro, G. M., Lopez, J. E. N. \& Saez, P. L. (2006). Business and Social Reputation: Exploring the Concept and Main Dimensions of Corporate Reputation. Journal of Business Ethics. 63(4). 361-370. 
Deephouse, D. L. (2000). Media Reputation as a Strategic Resource: An Integration of Mass Communication and Resource-Based Theories. Journal of Management. 26(6). 1091-1112.

Detomasi, D. A. (2006). International Regimes: The Case of Western Corporate Governance. International Studies Review. 8. 225-251.

Dicken, F. P. (1992). Global Shift: The Internationalization of Economic Activity. New York: Guilford Press.

Dickey, D. \& Fuller, W. (1979). Disturbition of Estimatiors for Autoregressive Time Series with a Unit Root. Journal of the American Statistical Association. 74. 427-431.

Dickey, D. \& Fuller, W. (1981). Likelihood Ratio Statistics for Autoregressive Time Series with a Unit Root. Econometrica. 49(4). 1057-1072.

Dutton, J. \& Dukerich J. (1991). Keeping an Eye on the Mirror: Image and Identity in Organizational Adaptation. Academy of Management Journal. 34: 517-554.

Filatotchev, I. \& Nakajima, C. (2014). Corporate Governance, Responsible Managerial Behavior and Corporate Social Responsibility: Organizational Efficiency versus Organizational Legitimacy?. The Academy of Management Perspectives. 28(3). 289-306.

Fombrun, C. \& Shanley M. (1990). What's in a Name? Reputation Building and Corporate Strategy. Academy of Management Journal. 33(2). 233-258.

Freeman, R. E. (1984). Strategic Management: A Stakeholder Approach. Boston: Pitman.

Goffman, E. (1959). The Presentation of Self in Everyday Life. New York: Doubleday.

Gotsi, M. \& Wilson, A. (2001). Corporate Reputation: Seeking a Definition. Corporate Communication: An International Journal, 6(1). 24-30.

Grant, P. \& Mc Ghee, P. (2014). Corporate Governance Reform: Character-Building Structures. Business Ethics: A European Review. 23(2). 125-138.

Greenbury Report. (1995). Directors' Remuneration, Report of a Study Group chaired by Sir Richard Greenbury. http://www.ecgi.org Erişim Tarihi: 27.07.2017.

Hampel Report. (1998). Committee on Corporate Governance Final Report. http://www.ecgi.org Erişim Tarihi: 27.07.2017.

Hart, S. L. (1997). Beyond Greening: Strategies for a Sustainable World. Harvard Business Review. 75(1). 66-77.

Heider, F. (1958). The Psychology of Interpersonal Relations. New York: Wiley.

Høgevold, N. M. \& Svensson, G. (2012). A Business Sustainability Model: A European Case Study. Journal of Business \& Industrial Marketing. 27(2). 142-151.

Hussainey, K. \& Al-Najjar, B. (2012). Understanding the Determinants of Risk Metrics/ISS Ratings of the Quality of UK Companies' Corporate Governance Practice. Canadian Journal of Administrative Sciences, 29. 366-377.

Isaksson, R. \& Steimle, U. (2009). What Does Gri-Reporting Tell Us About Corporate Sustainability?. The TQM Journal, 21(2). 168-181.

Janggu, T., Darus, F., Zain, M. M. \& Sawani, Y. (2014). Does Good Corporate Governance Lead to Better Sustainability Reporting? An Analysis Using Structural Equation Modeling. Procedia Social and Behavioral Sciences. 145(2014). 138-145.

Jizi, M. I., Salama, A., Dixon, R. \& Stratling, R. (2014). Corporate Governance and Corporate Social Responsibility Disclosure: Evidence from the US Banking Sector. J Bus Ethics. 125. 601-615.

Jo, H. \& Harjoto, M. A. (2011). Corporate Governance and Firm Value: The Impact of Corporate Social Responsibility. Journal of Business Ethic. 103. 351-383.

Johansen, S. (1991). Estimation and Hypothesis Testing of Cointegration Vectors in Gaussian Vector Autoregressive Models. Econometrica. 59(6). 1551-1580.

Kamal, Y. \& Deegan, C. (2013). Corporate Social and Environment-Related Governance Disclosure Practices in the Textile and Garment Industry: Evidence from a Developing Country. Australian Accounting Review. 65(23). 117-134.

Krechovská, M. \& Procházková, P. T. (2014). Sustainability and its Integration into Corporate Governance Focusing on Corporate Performance Management and Reporting. Procedia Engineering. 69. 1144-1151. 
Krüger, P. (2014). Corporate Goodness and Shareholder Wealth. Journal of Financial Economics. 115. 304-329.

Lewis, S. (2003). Reputation and Corporate Responsibility. Journal of Communication Management. 7(4). 356-366.

Mc Combs, M. E. \& Shaw, D. L. (1972). The Agenda-Setting Function of Mass Media. Public Opinion Quarterly. 36(2). 176-187.

Melo, T. \& Garrido-Morgado, A. (2012). Corporate Reputation: A Combination of Social Responsibility and Industry. Corporate Social Responsibility and Environmental Management. 19. 11-31.

Michelon, G. \& Parbonetti, A. (2012). The Effect of Corporate Governance on Sustainability Disclosure. Journal of Managment \& Government. 16. 477-509.

Musteen, M., Datta, D. K. \& Kemmerer, B. (2010). Corporate Reputation: Do Board Characteristics Matter?. British Journal of Management. 21. 498-510.

Myners Report. 2001. Institutional Investment in the United Kingdom: A Review. http://uksif.org Erişim Tarihi: 27.07.2017.

Nidumolu, R., Prahalad, C. K. \& Rangaswami, M. R. (2009). Why Sustainability Is Now The Key Driver of Innovation. Harvard Business Review. 87(9). 56-64.

OECD (Organization for Economic Co-operation and Development). (1999). OECD Principles of Corporate Governance. http://www.ecgi.org Erişim Tarihi: 27.07.2017.

OECD (Organization for Economic Co-operation and Development). (2004). OECD Principles of Corporate Governance. http://www.oecd.org Erişim Tarihi: 27.07.2017.

Özsoy, Z. (2011). Kurumsal Yönetim ve Yönetim Kurulları. Ankara: İmge Kitabevi.

Pauly, L.W. \& Reich, S. (1997). National Structures and Multinational Corporate Behavior: Enduring Differences in the Age of Globalization, International Organization. Winter 97. 51(1). 1-30.

Pearson, K. (1895). Notes on Regression and Inheritance in the Case of Two Parents. Proceedings of the Royal Society of London. 58. 240-242.

Pearson, K. (1900). On the Criterion that a Given System of Deviations from the Probable in the Case of a Correlated System of Variables Is Such that It Can Be Reasonably Supposed to Have Arisen from Random Sampling. Philosophical Magazine. Series 5. 50(302). 157 175.

Petrocik, J. R., Benoit, W. L. \& Hansen, G. J. (2003). Issue Ownership and Presidential Campaigning: 1952-2000. Political Science Quarterly. 118. 599-626.

Pfarrer M. D., Pollock T. G. \& Rindova V. P. (2010). A Tale of Two Assets: The Effects of Firm Reputation and Celebrity on Earnings Surprises and Investors' Reactions. Academy of Management Journal. 53(5). 1131-1152.

Porter, M. E. (1980). Competitive Strategy. New York: Free Press.

Sarbanes-Oxley Act. (2002). Public Law. 107-204, https://www.sec.gov Erişim Tarihi: 27.07.2017.

Schnietz K. E. \& Epstein M. J. (2005). Exploring the Financial Value of a Reputation for Corporate Social Responsibility during a Crisis. Corporate Reputation Review. 7(4). 325-345.

Sevüktekin, M. \& Nargeleçekenler, M. (2010). Ekonometrik Zaman Serileri Analizi: Eviews Uygulamalı. Ankara: Nobel Yayın Dağıtım.

Sharma, J. P. \& Khanna S. (2014). Corporate Social Responsibility, Corporate Governance and Sustainability: Synergies and Inter-Relationships. Indian Journal of Corporate Governance. 7(1). 14-18.

Sipahi, B., Yurtkoru, E. S. \& Çinko, M. (2008). Sosyal Bilimlerde Spss'le Veri Analizi. İstanbul: Beta Basım Yayım Dağıtım.

Solomon A. \& Solomon J. F. (1999). Empirical Evidence of Long-Termism and Shareholder Activism in UK Unit Trusts. Corp Governance: An International Review. 7. 288-299.

Spence, M. (1973). Job market signaling. Quarterly Journal of Economics. 87. 355-379.

Stuebs, M. \& Sun L. (2015). Corporate Governance and Social Responsibility. International Journal of Law and Management. 57(1). 38-52.

Turnbull Report. (1999). Internal Control, Guidance for Directors on the Combined Code. The Institutes of Chartered Accountants. http://www.ecgi.org Erişim Tarihi: 27.07.2017. 
Walls, J., Berrone, P. \& Phan, P. H. (2012). Corporate Governance and Environmental Performance: Is There Really a Link?. Strategic Management Journal. 33. 885-913.

Yıldırtan, D. Ç. (2011). E-Views Uygulamalı Temel Ekonometri, İstanbul: Türkmen Kitabevi.

Zsolnai, L. (2002). Green Business or Community Economy?. International Journal of Economics. 29(8). 652-662.

http://www.tdk.gov.tr Erişim Tarihi: 27.07.2017.

\section{SUMMARY}

This paper is aim to investigates that how relationship there is corporate governance, corporate sustainability and corporate reputation. In this context, corporate governance, corporate sustainability and corporate reputation concepts constitutes research issue of the paper.

Although corporate governance had been more important with such as Enron, WorldCom, Arthur Anderson, AIG and Parmalat scandals in 2000s, it dates back into the earlier period of 1990s, is a system that firms is directed and controlled, guides into shareholders relationship of firms, contains all rules and applications written or not, includes business owners, members of the board of directors, employees, customers, suppliers, credit institutions (Solomon and Solomon, 1999; Paul and Reich, 1997; Özsoy, 2011; Colley, 2004; Hussainey and Al-Najjar, 2012; Walls et al., 2012).

Whereas sustainability concept have become popular with the published Brundtland Report titled "Our Common Future" in 1987, first form of the concept dates back into the earlier period of 1900s (Christofi et al., 2012). According to Brundtland Report, sustainability concept is defined as to ensure that it meets the needs of the present without compromising the ability of future generations to meet their own needs (Brundtland Report, 1987).

Corporate reputation concepts which it is very closely related to corporate identity and corporate image concepts collectively impressions about the firm that member of the social group. In addition to this, corporate reputation is defined as intangible resources of the company by leading competitive advantage (De Castro et al, 2006; Pfarrer et al., 2010; Chun, 2005; Deephouse, 2000; Schnietz and Epstein, 2005).

Borsa İstanbul Corporate Governance Index, Borsa İstanbul Corporate Sustainability Index and Brandfinance Turkey 100 was employed in this paper in order to explore the correlation between corporate governance, corporate sustainability and corporate reputation. As a result of Pearson correlation analysis, it was obtained positively strong correlation $(+0,965)$ between BIST XKURY Index and BIST XUSRD Index. According to Pearson correlation results $(+0,965)$, Hypothesis 1 is supported. Before Johansen system co-integration analysis, ADF test (Dickey and Fuller, 1981) is employed to identify the issues if series of the indexes have unit root and stabilize at the same level or not. As a result of ADF test, whereas BIST XUSRD Index have 0,3084 critical value at the level, BIST XKURY Index have 0,2803 critical value at the level. Though that's why both BIST XKURY Index and BIST XUSRD Index series significantly 0,0000 critical value when the series is applied with first difference, it is 
expressed that the series have not unit root, so both of them have stabilized. Because of this situation, Hypothesis $2 \mathrm{a}$ and Hypothesis $2 \mathrm{~b}$ are accepted. After stable of the series is determined at the first difference, Johansen system cointegration analysis (Johansen, 1991) is employed to identify if BIST XKURY Index and BIST XUSRD Index series act or not together in the long term. As a result of Johansen system co-integration analysis, trace statistics value is greater than critical value. Also, because of the fact that max-eigen statistics value is higher level than critical value (7.449105>3.841466), there is one co-integration vector at least. According to these results, Hypothesis 3 is supported. In this case, it is accepted that BIST XKURY Index and BIST XUSRD Index act together in the long term. Positive relationship between BIST XKURY Index and BIST XUSRD Index is supported by literature too (Jo and Harjoto, 2011; Cong and Freedman, 2011; Janggu et al., 2014; Sharma and Khanna, 2014; Jizi et al., 2014; Chan et al., 2014; Stuebs and Sun, 2015). Lastly, common six firms take place in BIST XKURY Index, BIST XUSRD Index and Brandfinance Turkey 100 are examined to explore the effects of corporate governance and corporate sustainability on corporate reputation.

It was explored that BIST XKURY Index average, BIST XUSRD Index average and total brand value of six common firms have been increased. The papers which explain effects of corporate governance or sustainability on reputation is rather available in the literature (Fombrun and Shanley, 1990; Musteen et al., 2010; Brammer and Pavelin, 2006; Melo and Garrido-Morgado, 2012). When the research findings are assessed, there is a positive relationship between corporate governance, corporate sustainability and corporate reputation.

Within the framework Freeman's shareholder theory (Freeman, 1984) and Azapagic's system approach (Azapagic, 2003), corporate governance is cointegrated by being harmonized sustainability elements which are economic, social and environmental structures. These two structures (governance and sustainability) in the organization will leads on enhanced corporate reputation. Finally the triple column which is essential for the organization will make organizations successful. 